\title{
Study of Environmental Radiation on Sand and Soil Samples from Kuakata Sea Beach of Patuakhali
}

\author{
Khondaker Mohammed Nazrul Islam', Debasish Paul', Md. Mahbubur Rahman Bhuiyan ${ }^{3 *}$ \\ Amina Akter ${ }^{1}$, Budrun Neher ${ }^{3}$, Sheikh Mohammad Azharul Islam ${ }^{1}$ \\ ${ }^{1}$ Department of Physics, Jahangirnagar University, Savar, Bangladesh; ${ }^{2}$ Health Physics \& Radioactive Waste Management Unit (HP \\ \& RWMU), Institute of Nuclear Science \& Technology (INST), Atomic Energy Research Establishment (AERE), Savar, Bangladesh; \\ ${ }^{3}$ Department of Physics, Comilla University, Comilla, Bangladesh. \\ Email: *rahmanmahbubur@ymail.com
}

Received June 15 ${ }^{\text {th }}$, 2012; revised July 10 ${ }^{\text {th }}$, 2012; accepted August $7^{\text {th }}, 2012$

\begin{abstract}
The activity concentrations of radionuclides in the sand and soil samples collected from Kuakata seabeach of Patuakhali district in Bangladesh have measured using a high resolution high purity germanium (HPGe) detector of relative efficiency $40 \%$. The activity concentrations of ${ }^{226} \mathrm{Ra},{ }^{232} \mathrm{Th}$ and ${ }^{40} \mathrm{~K}$ were found in the sand samples of Kuakata seabeach varied from $2.82 \pm 4.89$ to $87.96 \pm 4.45 \mathrm{~Bq} \cdot \mathrm{Kg}^{-1}, 21.72 \pm 16.27$ to $290.93 \pm 18.15 \mathrm{~Bq} \cdot \mathrm{Kg}^{-1}$ and $26.24 \pm 0.35$ to 852.05 $\pm 142.15 \mathrm{~Bq} \cdot \mathrm{Kg}^{-1}$ respectively. For soil samples the activity concentrations of corresponding radionuclides were found to be $20.98 \pm 3.96$ to $42.92 \pm 4.76 \mathrm{~Bq} \cdot \mathrm{Kg}^{-1}$, $59.25 \pm 15.62$ to $144.34 \pm 18.52 \mathrm{~Bq} \cdot \mathrm{Kg}^{-1}$ and $570.43 \pm 100.3$ to $1165 \pm$ $166.27 \mathrm{~Bq} \cdot \mathrm{Kg}^{-1}$ respectively. The average absorbed dose rate due to radionuclides in sand was estimated to range from 51.84 to $246.55 \mathrm{nGy} \cdot \mathrm{h}^{-1}$ with an average of $98.33 \mathrm{nGy} \cdot \mathrm{h}^{-1}$. Also the average absorbed dose rate due to radionuclides in soil was estimated to range from $76.63 \mathrm{nGy} \cdot \mathrm{h}^{-1}$ to $142.36 \mathrm{nGy} \cdot \mathrm{h}^{-1}$ with an average of $110.04 \mathrm{nGy} \cdot \mathrm{h}^{-1}$. Radium equivalent activities were calculated for the analyzed samples to assess the radiation hazards arising due to the presence of this radionuclide in the samples. Most of the calculated radium equivalent activities are lower than the limit set in the OECD report $\left(370 \mathrm{~Bq} \cdot \mathrm{kg}^{-1}\right)$. The measured representative level index values for the investigated samples varied in the range 0.8 to 3.75 .
\end{abstract}

Keywords: Radionuclide; Activity Concentration; HPGe detector; Kuakata Seabeach; ${ }^{226} \mathrm{Ra} ;{ }^{232} \mathrm{Th} ;{ }^{40} \mathrm{~K}$ and ${ }^{137} \mathrm{Cs}$

\section{Introduction}

Radiation is present in every environment of the Earth's surface, beneath the Earth and in the atmosphere. According to UNSCEAR (1993), about $87 \%$ of the radiation dose received by mankind is due to natural radiation sources and the remaining is due to anthropogenic radiation [1]. It is observed that most of natural radioactive elements present in soil are primordial radionuclides from the uranium series, thorium series, and ${ }^{40} \mathrm{~K}$ [2]. The man and the animal kingdom however make adjustment to the natural radiation sources. But the advent of artificial or man-made radiation sources, when man succeeded in fissioning of the uranium atomic nucleus, their widespread application and accidental uncontrolled release of radioactivity in the environment have altered the balance. Nuclear weapons test release radioactive fissions products into the atmosphere and its depositions over the earth's surface are termed "fallout". The distribution of this fallout in the environment takes place in various

*Corresponding author. ways depending on the strength of the nuclear device, mode of burst and climate conditions. Significant amounts of man-made radionuclides, ${ }^{137} \mathrm{Cs}$ and ${ }^{90} \mathrm{Sr}$, are also present in the environment as a result of nuclear weapon tests and nuclear accidents [1].

Radionuclides can be deposited to the sand and soil in various ways. The uranium, thorium series and potassium- 40 are the most common radionuclides present in most material. All radionuclides release ionizing radiation. Ionizing radiation may cause cancer. Any amount of radiation dose may cause stochastic effect (e.g. cancer etc.). Uncontrolled radiation from any source is harmful to the occupational workers, public and environment.

Assessment of any release of radioactivity to the environment is important for the protection of public health; especially if the released radioactivity is a matter of direct population exposure and can enter into the food chain [3].

Beach sand or soil is mineral deposits formed through the weathering and erosion of rocks. These deposits found at different levels within the sand contain natural 
radionuclides that contribute to ionizing radiation exposure on earth [4]. Kuakata Seabeach of Patuakhali is one of the attractive tourist places in Bangladesh. An attempt has made in this study to determine the concentration of ${ }^{238} \mathrm{U},{ }^{232} \mathrm{Th},{ }^{40} \mathrm{~K}$ and ${ }^{137} \mathrm{Cs}$ in beach sand and soil samples collected from Kuakata Seabeach of Patuakhali using HPGe gamma ray spectrometer and to compute the total absorbed gamma dose rate in air due to the presence of ${ }^{238} \mathrm{U},{ }^{232} \mathrm{Th}$ and ${ }^{40} \mathrm{~K}$ in the samples.

\section{Materials and Method}

\subsection{The Study Area}

Kuakata Seabeach is the area of interest in the present study, which is located at Patuakhali district in Bangladesh. The study area is situated at about 65 kilometer away and to the north of Patuakhali. The locations of sample collection are shown in Figure 1. The sand samples were collected from the beach area while the soil samples were collected from adjacent locality around the beach.

\subsection{Collection and Preparation of Samples}

For the measurement of natural radionuclides at the study area, a total of 15 sand samples and 7 soil samples were collected from in and around the seabeach areas. Each sample was taken maintaining a distance of about $1 \mathrm{~km}$ from each other. About $0.75-1.00 \mathrm{~kg}$ of sample was collected from each location and each of the samples was placed in plastic packet and transported to the laboratory. Each of the collected sand and soil samples was first

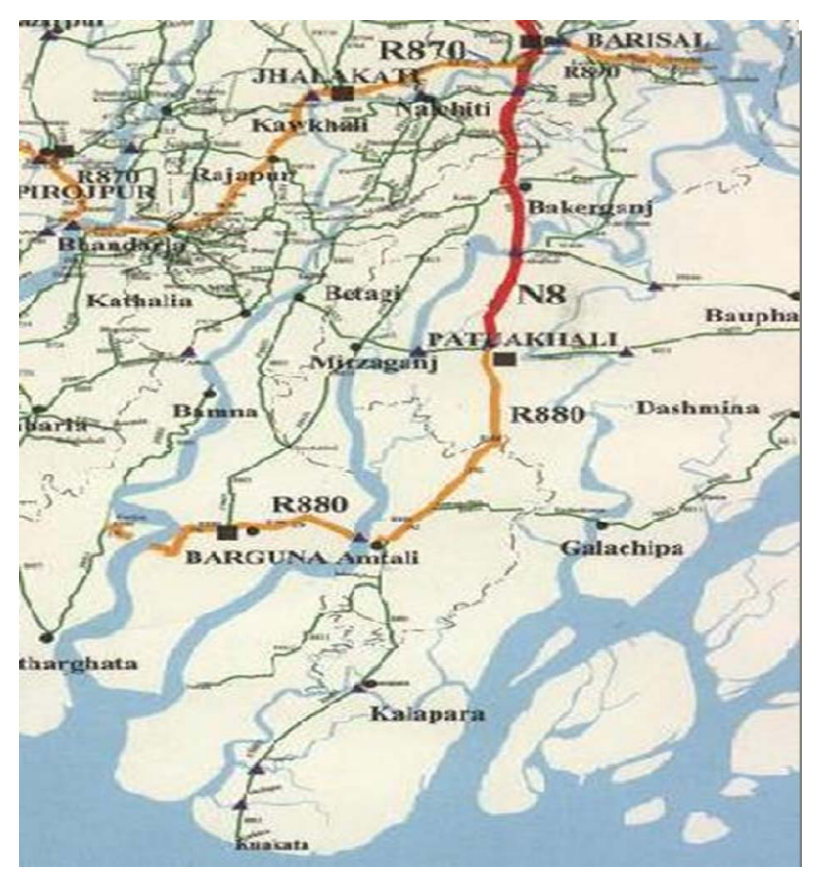

Figure 1. Geographical location of SAMPLING area. weighed, then dried at about $110^{\circ} \mathrm{C}$ in an oven for 24 hours and there after ground into a fine powder with a grinder and collected after passing through a 10-mesh screen. Thus, homogenized sample was transferred to sealable cylindrical plastic container of $7 \mathrm{~cm}$ height and $5.5 \mathrm{~cm}$ in diameter, marked individually with identification parameters. All the sample containers were sealed tightly with cap and wrapped with Teflon and thick vinyl tapes around their screw necks and finally air tightened with polythene pack and stored for minimum four weeks prior to counting, allowing establishment of secular equilibrium between the long lived ${ }^{238} \mathrm{U},{ }^{232} \mathrm{Th}$ and their decay products.

\subsection{Data Collection and Analysis}

After adjustment of necessary parameters such as resolution, peak to Compton ratio etc. and measurement of minimum detectable activity of the detectors, each of the collected samples was placed on the top of the HPGe detector within the shielding arrangement and counted for above 10,000 seconds. Gamma ray spectrometry can be used to identify gamma ray energies and consequently the radioactive species which are producing them. The area under the peak in a gamma ray spectrum represents the number of counts collected for only that gamma ray energy. These peak areas were used for determination of radioactivity concentration of the radionuclides present in the sample. The net count of the sample is obtained by subtracting a linear background distribution of the pulse height spectra from the corresponding peak energy area. From the net counts of the samples activity concentration of the radionuclides were calculated using the formula

$$
A=\frac{\mathrm{CPS} \times 1000}{\varepsilon(a b s) \times I_{r}(a b s) \times W}
$$

where, $A$ is the activity concentration in $\mathrm{Bq} \cdot \mathrm{kg}^{-1}$, CPS is the net peak counts per second of the samples, $W$ is the weight of the sample in gm, $\varepsilon(a b s)$ is the absolute gamma peak detection efficiency, $I_{r}(a b s)$ is the absolute gamma intensity of the corresponding gamma ray energy. Gamma rays intensities were taken from the literature [5]. The peak detection efficiencies were calculated from the full energy peak detection efficiency curve plotted using $\mathrm{Al}_{2} \mathrm{O}_{3}$ based ${ }^{226} \mathrm{Ra}$ standard as shown Figure 2. The error in the measurement have been expressed in terms of standard deviation $( \pm 2 \sigma)$, where $\sigma$ is expressed as,

$$
\sigma=\left[\frac{N_{s}}{T_{s}^{2}}+\frac{N_{b}}{T_{b}^{2}}\right]^{1 / 2}
$$

where $N_{s}$ is the counts measured in time $T_{s}$ and $N_{b}$ is the background counts measured in time $T_{b}$. The standard deviation $\pm 2 \sigma$ in CPS was converted into activity concentration in $\mathrm{Bq} \cdot \mathrm{Kg}^{-1}$ according to Equation (1). 


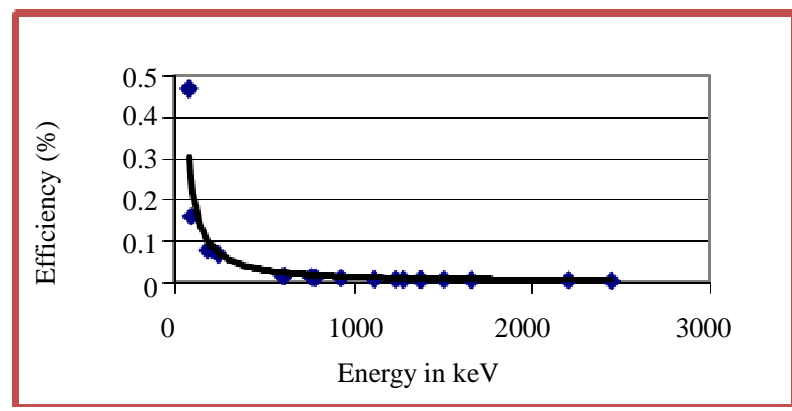

Figure 2. Efficiency curve of HPGe detector.

Most prominent gamma energy peaks of $351.92 \mathrm{keV}$ (due to ${ }^{214} \mathrm{~Pb}$ ) and $609.31 \mathrm{keV}$ (due to ${ }^{214} \mathrm{Bi}$ ) were used to determine ${ }^{226} \mathrm{Ra}$; $911.07 \mathrm{keV}$ (due to ${ }^{228} \mathrm{Ac}$ ) and 969.11 $\mathrm{keV}$ (due to ${ }^{228} \mathrm{Ac}$ ) were used to determine ${ }^{232} \mathrm{Th} ; 1460.75$ $\mathrm{keV}$ was used to determine ${ }^{40} \mathrm{~K}$ and $661.66 \mathrm{keV}$ was used to determine ${ }^{137} \mathrm{Cs}$.

\subsection{Radiological Hazard Assessment}

\subsubsection{Radium Equivalent Activities}

The radium equivalent activity is an index that represents the specific activities of ${ }^{226} \mathrm{Ra},{ }^{232} \mathrm{Th}$ and ${ }^{40} \mathrm{~K}$ by a single quantity which takes into account the radiation hazards associated with them. This can be calculated using the equation below [4] as

$$
\mathrm{Ra}_{e q}=C_{\mathrm{Ra}}+1.43 C_{\mathrm{Th}}+0.077 C_{\mathrm{K}}
$$

where $C_{\mathrm{Ra}}, C_{\mathrm{Th}}$ and $C_{\mathrm{K}}$ are the specific activities of ${ }^{226} \mathrm{Ra}$, ${ }^{232} \mathrm{Th}$ and ${ }^{40} \mathrm{~K}$ in Bq$\cdot \mathrm{Kg}^{-1}$ respectively. The maximum value of $\mathrm{Ra}_{e q}$ in building materials must be $<370 \mathrm{~Bq} \cdot \mathrm{Kg}^{-1}$ for safe use [4].

\subsubsection{Representative Level Index Values}

Another radiation hazard index called the representative level index, used to estimate the level of gamma radiation associated with different concentrations of some specific radionuclides, can be defined as follows [6]

$$
I_{\gamma r}=\frac{C_{\mathrm{Ra}}}{150}+\frac{C_{\mathrm{Th}}}{100}+\frac{C_{\mathrm{K}}}{1500}
$$

where $C_{\mathrm{Ra}}, C_{\mathrm{Th}}, C_{\mathrm{K}}$ are the specific activities of ${ }^{226} \mathrm{Ra}$, ${ }^{232} \mathrm{Th}$ and ${ }^{40} \mathrm{~K}$ in $\mathrm{Bq} \cdot \mathrm{Kg}^{-1}$ were calculated for the samples under investigation to indicate different levels of external $\gamma$-radiation due to different combination of specific natural activities in other materials. This index can be used to estimate the level of $\gamma$-radiation hazard associated with the natural radionuclide in the materials.

\subsubsection{Dose Rate Calculation}

The formula given in the UNSCEAR (1998) report was used to estimate the absorbed gamma dose rate in outdoor air due to natural radionuclides from the beach sand and soil one metre above the surface [1] as

$$
D=0.427 C_{\mathrm{Ra}}+0.662 C_{\mathrm{Th}}+0.0432 C_{\mathrm{K}}
$$

where $C_{\mathrm{Ra}} C_{\mathrm{Th}}$ and $C_{\mathrm{K}}$ are specific activities of ${ }^{226} \mathrm{Ra}$, ${ }^{232} \mathrm{Th}$ and ${ }^{40} \mathrm{~K}$ in $\mathrm{Bq} \cdot \mathrm{Kg}^{-1}$. The total absorbed dose rate for the present studied samples from a height of one meter above the ground surface as shown in Table 3.

\section{Results and Discussions}

The natural radioactivity level of sand and soil samples collected from Kuakata sea beach of Patuakhali district in Bangladesh were measured using high purity germanium (HPGe) detector. The activity concentration of ${ }^{226} \mathrm{Ra}$ in sand samples ranged from $2.82 \pm 4.89$ to $87.96 \pm$ $4.45 \mathrm{~Bq} \cdot \mathrm{Kg}^{-1}$ with an average value of $29.48 \pm 3.85$ $\mathrm{Bq} \cdot \mathrm{Kg}^{-1}$. The concentration of ${ }^{232} \mathrm{Th}$ in sand samples ranged from $21.72 \pm 16.27$ to $290.93 \pm 18.15 \mathrm{~Bq} \cdot \mathrm{Kg}^{-1}$ with an average value of $93.72 \pm 15.62 \mathrm{~Bq} \cdot \mathrm{Kg}^{-1}$ and the concentration of ${ }^{40} \mathrm{~K}$ in sand samples ranged from 26.24 \pm 0.35 to $852.05 \pm 142.15 \mathrm{~Bq} \cdot \mathrm{Kg}^{-1}$ with an average value of $551.24 \pm 109.95 \mathrm{~Bq} \cdot \mathrm{Kg}^{-1}$.

The activity concentration of ${ }^{226} \mathrm{Ra}$ in soil samples ranged from $20.98 \pm 3.96$ to $42.92 \pm 4.76 \mathrm{~Bq} \cdot \mathrm{Kg}^{-1}$ with an average value of $29.19 \pm 4.88 \mathrm{~Bq} \cdot \mathrm{Kg}^{-1}$. The activity concentration of ${ }^{232} \mathrm{Th}$ in soil samples ranged from 59.25 \pm 15.62 to $144.34 \pm 18.52 \mathrm{~Bq} \cdot \mathrm{Kg}^{-1}$ with an average value of $90.56 \pm 17.94 \mathrm{~Bq} \cdot \mathrm{Kg}^{-1}$ and the concentration of ${ }^{40} \mathrm{~K}$ in soil samples ranged from $570.43 \pm 100.3$ to $1165 \pm$ 166.27 $\mathrm{Bq} \cdot \mathrm{Kg}^{-1}$ with an average value of $874.89 \pm$ $119.96 \mathrm{~Bq} \cdot \mathrm{Kg}^{-1}$.

The mean activity concentration of ${ }^{226} \mathrm{Ra},{ }^{232} \mathrm{Th}$ and ${ }^{40} \mathrm{~K} \mathrm{~Bq} \cdot \mathrm{Kg}^{-1}$; range and mean values of activity concentrations; radium equivalent activities $\left(\mathrm{Ra}_{e q}\right)$ in $\mathrm{Bq} \cdot \mathrm{Kg}^{-1}$, representative level index values $\left(I_{\gamma}\right)$, dose rate (D) in $\mathrm{nGy} \cdot \mathrm{h}^{-1}$ are shown in the Tables 1-3 respectively. The mean activity concentration of ${ }^{226} \mathrm{Ra},{ }^{232} \mathrm{Th}$ and ${ }^{40} \mathrm{~K}$ in sand and soil samples are shown graphically in Figures 3 and 4 respectively. Since no ${ }^{137} \mathrm{Cs}$ radionuclide was detected in any of the sand and soil samples, it indicates that there is no fission product present in the sand and soil samples of Kuakata seabeach.

From the activities given in Table 1, activity ratios of ${ }^{232} \mathrm{Th}$ and ${ }^{226} \mathrm{Ra}$ were computed for all the sand and soil samples. These ratios $\left({ }^{232} \mathrm{Th} /{ }^{226} \mathrm{Ra}\right)$ varied from 1.68 to 8.57 (mean: 4.45) for all the sand samples and 2.14 to 4.57 (mean: 3.17) for all the soil samples indicating that the concentration of ${ }^{232} \mathrm{Th}$ is greater than that of ${ }^{226} \mathrm{Ra}$.

From Table 1, it has observed that the mean activity of ${ }^{226} \mathrm{Ra}$ (29.48) in sand is about 1.18 times higher than that of the world average (25 Bq. $\left.\mathrm{Kg}^{-1}\right)$ [7] and the mean activity of ${ }^{226} \mathrm{Ra}$ (29.19) in soil is about 1.17 times higher than that of the world average $\left(25 \mathrm{~Bq} \cdot \mathrm{Kg}^{-1}\right)$ [7], whereas the mean activity of ${ }^{232} \mathrm{Th}$ (93.72) in sand is about 3.75 times higher than that of the world average $\left(25 \mathrm{~Bq} \cdot \mathrm{Kg}^{-1}\right)$ [7] and the mean activity of ${ }^{232} \mathrm{Th}$ (90.56) in soil is about 
Table 1. The mean activity concentration of the measured radionuclides in sand and soil samples in Kuakata seabeach of Patuakhali.

\begin{tabular}{|c|c|c|c|c|}
\hline \multirow{2}{*}{ Name of sample } & \multicolumn{4}{|c|}{ Specific activity of radionuclides in $\mathbf{B q} \cdot \mathbf{K g}^{-1} \pm 2 \sigma$} \\
\hline & ${ }^{226} \mathbf{R a}$ & ${ }^{232} \mathrm{Th}$ & ${ }^{40} \mathbf{K}$ & ${ }^{137} \mathrm{Cs}$ \\
\hline \multicolumn{5}{|c|}{ Sand Sample of Kuakata } \\
\hline K.S-1 & $42.39 \pm 4.33$ & $150.68 \pm 13.8$ & $26.24 \pm 0.35$ & ND \\
\hline K.S-2 & $13.29 \pm 3.28$ & $48.195 \pm 13.64$ & $516.16 \pm 122.92$ & ND \\
\hline K.S-3 & $16.70 \pm 0.29$ & $143.22 \pm 15.71$ & $540.74 \pm 118.00$ & ND \\
\hline K.S-4 & $18.62 \pm 3.33$ & $58.53 \pm 16.81$ & $669 \pm 129.96$ & ND \\
\hline K.S-5 & $10.42 \pm 2.01$ & $61.23 \pm 7.97$ & $479 \pm 63.94$ & ND \\
\hline K.S-6 & $87.96 \pm 4.45$ & $81.32 \pm 17.16$ & $545.32 \pm 126.22$ & ND \\
\hline K.S-7 & $17.35 \pm 4.09$ & $61.22 \pm 10.05$ & $515.66 \pm 115.63$ & ND \\
\hline K.S-8 & $2.82 \pm 4.89$ & $21.72 \pm 16.27$ & $843.28 \pm 129.6$ & ND \\
\hline K.S-9 & $85.26 \pm 4.60$ & $290.93 \pm 18.15$ & $408.02 \pm 104.22$ & ND \\
\hline K.S-10 & $39.89 \pm 4.24$ & $139.53 \pm 16.6$ & $412.41 \pm 104.26$ & ND \\
\hline K.S-11 & $22.09 \pm 4.66$ & $80.59 \pm 17.4$ & $562.57 \pm 125.52$ & ND \\
\hline K.S-12 & $11.28 \pm 4.6$ & $72.39 \pm 18.42$ & $766.86 \pm 135.9$ & ND \\
\hline K.S-13 & $54.20 \pm 4.10$ & $91.50 \pm 16.92$ & $542.05 \pm 119.85$ & ND \\
\hline K.S-14 & $6.60 \pm 4.70$ & $44.55 \pm 18.58$ & $852.05 \pm 142.15$ & ND \\
\hline K.S-15 & $13.33 \pm 4.23$ & $60.17 \pm 16.80$ & $589.26 \pm 124.76$ & ND \\
\hline \multicolumn{5}{|c|}{ Soil sample of Kuakata } \\
\hline K.M-1 & $32.28 \pm 5.46$ & $69.24 \pm 12.7$ & $1073 \pm 154.85$ & ND \\
\hline K.M-2 & $42.92 \pm 4.76$ & $144.34 \pm 18.52$ & $662.27 \pm 115.11$ & ND \\
\hline K.M-3 & $20.98 \pm 3.96$ & $59.25 \pm 15.62$ & $661.67 \pm 11.1$ & ND \\
\hline K.M-4 & $31.53 \pm 5.39$ & $88.26 \pm 20.24$ & $1052.71 \pm 151.91$ & ND \\
\hline K.M-5 & $30.12 \pm 4.49$ & $66.33 \pm 18.61$ & $939.186 \pm 140.23$ & ND \\
\hline K.M-6 & $24.17 \pm 4.39$ & $110.54 \pm 17.57$ & $570.43 \pm 100.3$ & ND \\
\hline K.M-7 & $22.37 \pm 5.69$ & $96.00 \pm 22.36$ & $1165 \pm 166.27$ & ND \\
\hline
\end{tabular}

Table 2. Range and mean value of activity concentrations of ${ }^{226} \mathrm{Ra},{ }^{232} \mathrm{Th} \&{ }^{40} \mathrm{~K}$ in $\mathrm{Bq} \cdot \mathrm{Kg}^{-1}$ of the samples.

\begin{tabular}{cccc}
\hline Radionuclides & Sample type & Minimum & Maximum \\
\hline${ }^{226} \mathbf{R a}$ & Sand & $2.82 \pm 4.89$ & $87.96 \pm 4.45$ \\
& Soil & $20.98 \pm 3.96$ & $42.92 \pm 4.76$ \\
${ }^{232} \mathbf{T h}$ & Sand & $21.72 \pm 16.27$ & $290.93 \pm 18.15$ \\
& Soil & $59.25 \pm 15.62$ & $144.34 \pm 18.52$ \\
${ }^{40} \mathbf{K}$ & Sand & $26.24 \pm 0.35$ & $852.05 \pm 142.15$ \\
& Soil & $570.43 \pm 100.3$ & $551.24 \pm 109.95$ \\
\hline
\end{tabular}


Table 3. Radium equivalent activities $\left(\mathrm{Ra}_{e q}\right)$ in $\mathrm{Bq} \cdot \mathrm{Kg}^{-1}$, Representative level index values $\left(I_{r}\right)$ in $\mathrm{Bq} \cdot \mathrm{Kg}^{-1}$, Dose rate $(\mathrm{D})$ in $n G y \cdot h^{-1}$ in Sand and Soil samples in Kuakata seabeach of Patuakhali.

\begin{tabular}{|c|c|c|c|}
\hline Sample ID. & $\mathbf{R a}_{e q}$ in $\mathrm{Bq} \cdot \mathrm{Kg}^{-1}$ & $I_{r}$ in $\mathrm{Bq} \cdot \mathrm{Kg}^{-1}$ & Dose rate in $\mathrm{nGy} \cdot \mathrm{h}^{-1}$ \\
\hline \multicolumn{4}{|c|}{ Sand sample of Kuakata } \\
\hline K.S-1 & 259.88 & 1.81 & 118.98 \\
\hline K.S-2 & 121.95 & 0.92 & 59.78 \\
\hline K.S-3 & 263.14 & 1.91 & 125.19 \\
\hline K.S-4 & 153.83 & 1.15 & 75.47 \\
\hline K.S-5 & 134.86 & 1.00 & 65.58 \\
\hline K.S-6 & 246.24 & 1.77 & 114.84 \\
\hline K.S-7 & 144.60 & 1.07 & 70.11 \\
\hline K.S- 8 & 98.81 & 0.80 & 51.84 \\
\hline K.S-9 & 532.71 & 3.75 & 246.55 \\
\hline K.S-10 & 271.17 & 1.94 & 127.14 \\
\hline K.S-11 & 180.65 & 1.33 & 86.97 \\
\hline K.S-12 & 173.85 & 1.31 & 85.71 \\
\hline K.S-13 & 226.78 & 1.64 & 107.02 \\
\hline K.S-14 & 135.91 & 1.06 & 68.95 \\
\hline K.S-15 & 144.75 & 1.08 & 70.86 \\
\hline \multicolumn{4}{|c|}{ Soil sample of Kuakata } \\
\hline K.M-1 & 213.91 & 1.63 & 105.76 \\
\hline K.M-2 & 300.32 & 2.17 & 142.36 \\
\hline K.M-3 & 156.66 & 1.17 & 76.63 \\
\hline K.M-4 & 238.80 & 1.79 & 117.16 \\
\hline K.M-5 & 197.29 & 1.49 & 97.16 \\
\hline K.M-6 & 226.17 & 1.64 & 108.03 \\
\hline K.M-7 & 249.35 & 1.89 & 123.19 \\
\hline
\end{tabular}

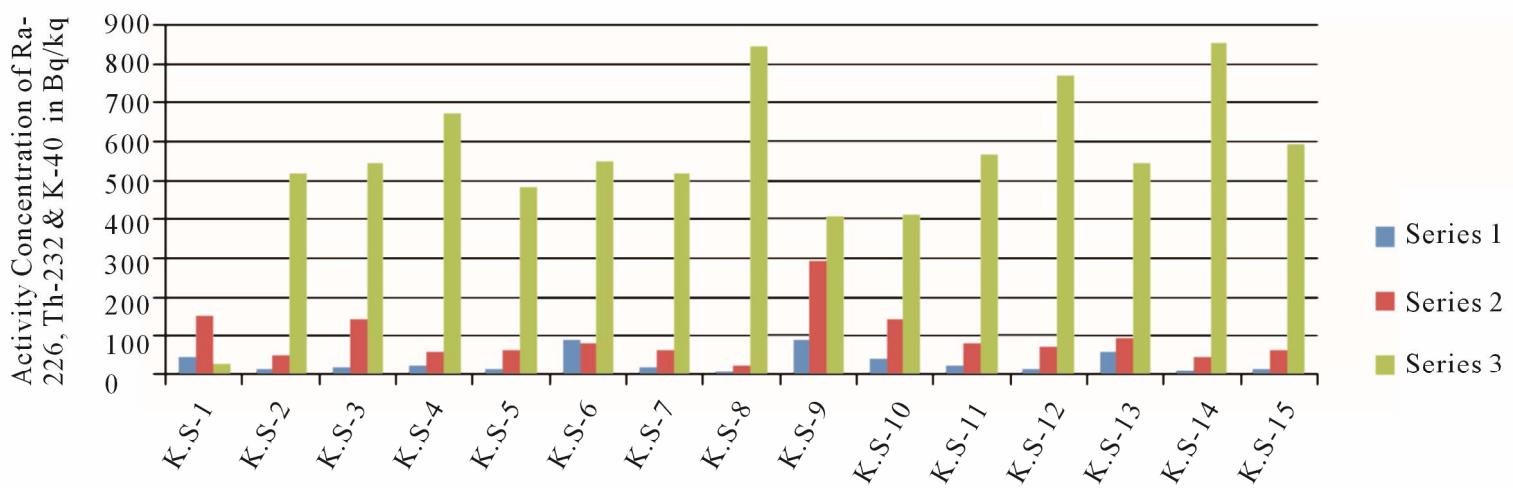

Sand Sample ID

Figure 3. Mean activity concentration of ${ }^{226} \mathrm{Ra},{ }^{232} \mathrm{Th} \&{ }^{40} \mathrm{~K}$ in $\mathrm{Bq} \cdot \mathrm{Kg}^{-1}$ in the sand samples. 


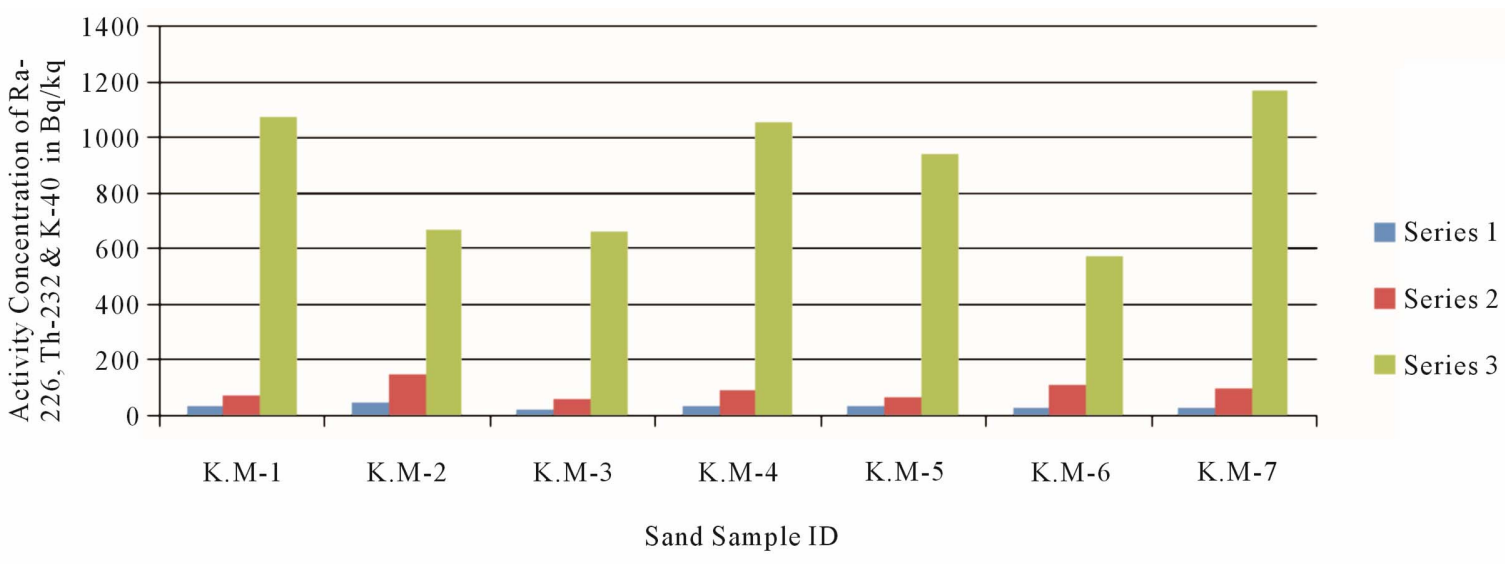

Figure 4. Mean activity concentration of ${ }^{226} \mathrm{Ra},{ }^{232} \mathrm{Th} \&{ }^{40} \mathrm{~K}$ in $\mathrm{Bq} \cdot \mathrm{Kg}^{-1}$ in the soil samples.

Table 4. Activity concentration of radionuclides in sand or soil samples from different parts of the world.

\begin{tabular}{|c|c|c|c|c|}
\hline Location & ${ }^{226} \mathrm{Ra}$ & ${ }^{232} \mathrm{Th}$ & ${ }^{40} \mathrm{~K}$ & Reference \\
\hline USA & $4-140$ & $4-130$ & $100-700$ & [10] \\
\hline Louisiana (USA) (soil) & $43-95$ & $50-190$ & $43-729$ & [11] \\
\hline Nile Delta (Egypt) (soil) & 17 & 19 & 316 & [12] \\
\hline Lake Nasser, Egypt & $4-41$ & $9-50$ & $16-487$ & [13] \\
\hline Dhaka City, Bangladesh & $21-43$ & $9-22$ & $402-705$ & [14] \\
\hline Chittagong, Bangladesh & $15-18$ & $7-39$ & $128-610$ & [15] \\
\hline Kalpakkam, Tamilnadu (soil) & $5-71$ & $15-776$ & $200-854$ & [1] \\
\hline Kalpakkam, Tamilnadu (sand) & $36-258$ & $352-3872$ & $324-405$ & {$[1]$} \\
\hline Peshwar, Pakistan & 65 & 84 & 646 & [16] \\
\hline Northeast Coast, Spain (sand) & $5-19$ & $5-44$ & $136-1087$ & [17] \\
\hline Kuwait & 36 & 6 & 227 & [18] \\
\hline Zircon, Bangladesh & 6439 & 1324 & 472 & [19] \\
\hline World average & 25 & 25 & 370 & [7] \\
\hline Sand of Kuakata seabeach & $29.48 \pm 3.85$ & $93.72 \pm 15.62$ & $551.24 \pm 109.95$ & Present study \\
\hline Soil of Kuakata seabeach & $29.19 \pm 4.88$ & $90.56 \pm 17.94$ & $874.89 \pm 119.96$ & Present study \\
\hline
\end{tabular}

3.62 times higher than that of the world average (25 $\mathrm{Bq} \cdot \mathrm{Kg}^{-1}$ ) [7]. ${ }^{40} \mathrm{~K}$ mean activity (551.24) in sand is 1.48 times higher than that of the world average (370 $\mathrm{Bq} \cdot \mathrm{Kg}^{-11}$ ) [7] and mean activity (874.89) in soil samples is 2.36 times higher than that of the world average (370 $\left.\mathrm{Bq} \cdot \mathrm{Kg}^{-1}\right)$ [7].

It can be observed from Table 3 that the calculated total dose rate due to the presence of ${ }^{226} \mathrm{Ra},{ }^{232} \mathrm{Th}$ and ${ }^{40} \mathrm{~K}$ in sand varied from 51.84 to $246.55 \mathrm{nGy} \cdot \mathrm{h}^{-1}$ with an average of $98.33 \mathrm{nGy} \cdot \mathrm{h}^{-1}$, which is 1.78 times higher than the world average value $\left(55 \mathrm{nGy} \cdot \mathrm{h}^{-1}\right)$ [8] and in soil varied from 76.63 to 142.36 with an average value of 110.04 $\mathrm{nGy} \cdot \mathrm{h}^{-1}$, which is 2 times higher than the world average value $\left(55 \mathrm{nGy} \cdot \mathrm{h}^{-1}\right)$ [8].

The experimental results of radium equivalent activity (Table 3) which indicate radiation hazards arising from the various beach samples (sand and soil) studies show that the average $\mathrm{Ra}_{e q}$ values are below the internationally acceptable value of $370 \mathrm{~Bq} \cdot \mathrm{Kg}^{-1}$ [9].

A comparative study was also performed for the activity concentrations in the present work with the other studies performed in home and aboard and is shown in the Table 4.

The activity concentrations of the radionuclides in the sand and soil samples collected from Kuakata seabeach are within the range of values reported in the other work 
performed in home and abroad.

\section{Conclusion}

The present environmental radiation level on the sand and soil of Kuakata seabeach at Patuakhali district in Bangladesh has been carried out by using gamma spectrometry system. The mean activity concentrations of ${ }^{226} \mathrm{Ra},{ }^{232} \mathrm{Th}$ and ${ }^{40} \mathrm{~K}$ in beach sand and soil, dose rate and other calculated hazard indices are comparable with the world average. The study also reflects that there is no fallout ${ }^{137} \mathrm{Cs}$ in the sand and soil samples of the area under investigation. Finally it can be concluded that no harmful radiation effects are pose to the public and tourists going to the beaches for recreation or to the sailors and fishermen involved in their activities in the area as a results of the activity of beach sand and soil.

\section{REFERENCES}

[1] V. Kannana, M. P. Rajana, M. A. R. Iyengara and R. Rameshb, "Distribution of Natural and Anthropogenic Radionuclides in Soil and Beach Sand Samples of Kalpakkam (India) Using Hyper Pure Germanium (HPGe) Gamma Ray Spectrometry," Applied Radiation and Isotopes, Vol. 57, No. 1, 2002, pp. 109-119. doi:10.1016/S0969-8043(01)00262-7

[2] S. U. El-Kameesy, S. Abd El-Ghany, S. M. El-Minyawi, Z. Miligy and E. M. El-Mabrouk, "Natural Radioactivity of Beach Sand Samples in the Tripoli Region, Northwest Libya," Turkish Journal of Engineering \& Environmental Science, Vol. 32, No. 1, 2008, pp. 245-251.

[3] IAEA, "Measurement of Radio-Nuclides in Food and the Environment,” IAEA Technical Report Series, No. 295, 1989.

[4] A. Amekudzie, G. Emi-Reynolds, A. Faanu, E. O. Darko, A. R. Awudu, O. Adukpo, L. A. N. Quaye, R. Kpordzro, B. Agyemang and A. Ibrahim, "Natural Radioactivity Concentrations and Dose Assessment in Shore Sediments along the Coast of Greater Accra, Ghana," World Applied Sciences Journal, Vol. 13, No. 11, 2011, pp. 2338-2343.

[5] International Atomic Energy Agency, "Measurement of Radionuclides in Food and the Environment: A Guidebook,” International Atomic Energy Agency, Vienna, 1989.

[6] NEA Group, "Nuclear Energy Agency, Exposure to Radiation from Natural Radioactivity in Building Materials,” OECD, Paris, 1979.

[7] United Nations Scientific Committee on the Effects of Atomic Radiation (UNSCEAR), "Sources, Effects and Risks of Ionising Radiation,” United Nations, New York, 1988.

[8] M. R. Abdil, H. Faghihian, M. Kamali, M. Mostajaboddavati and A. Hasanzadeh, "Distribution of Natural Ra- dionuclides on Coasts of Bushehr, Persian Gulf, Iran,” Iranian Journal of Science \& Technology: Transaction A, Vol. 30, No. A3, 2006, pp. 259-269.

[9] K. A. Kabir, S. M. A. Islam and M. M. Rahman, "Distribution of Radionuclides in Surface Soil and Bottom Sediment in the District of Jessore, Bangladesh and Evaluation of Radiation Hazard," Journal of Bangladesh Academy of Sciences, Vol. 33, No. 1, 2009, pp. 117-130.

[10] United Nations Scientific Committee on the Effects of Atomic Radiation (UNSCEAR), "Sources and Effects of Ionizing Radiation,” United Nations, New York, 1993.

[11] R. D. Delaune, G. L. Jones and C. J. Smith. "Radinuclides Concentrations in Louisiana Soils and Sediments," Health Physics, Vol. 51, No. 2, 1986, pp. 239-244.

[12] N. M. Ibrahiem, A. H. Abd El Ghani, S. M. Shawky, E. M. Ashraf and M. A. Farouk, "Measurement of Radioactivity Levels in the Nile Delta and Middle Egypt," Health Physics, Vol. 64, No. 6, 1993, pp. 620-627. doi:10.1097/00004032-199306000-00007

[13] N. M. Ibrahiem, S. Shawky and H. A. Amer, "Radioactivity Levels in Lake Nasser Sediments," Applied Radiation and Isotope, Vol. 46, No. 5, 1995, pp. 297-299. doi:10.1016/0969-8043(94)00144-O

[14] F. K. Miah, S. Roy, M. Touhiduzzaman and B. Alam, "Distribution of Radionuclides in Soil Samples in and around Dhaka City," Applied Radiation and Isotope, Vol. 49, No. 1, 1998, pp. 133-137. doi:10.1016/S0969-8043(97)00232-7

[15] M. N. Alam, M. I. Chowdhury, M. Kamal, M. A. R. Molla and M. A. Ammam, "Radioactivity Monitoring of Food and Environment Radioactivity Testing Laboratory, Chittagong," Bangladesh Atomic Energy Commission, RTL-1, October 1987-December 1990.

[16] S. Ali, M. Tufail, K. Jamie, A. Ahmed and H. A. Khan, "Gamma-Ray Activity and Dose Rate of Brick Samples from Some Area of North West Frontier Province (NWFP), Pakistan," Science of Total Environment, Vol. 187, No. 3, 1996, pp. 247-252. doi:10.1016/0048-9697(96)05109-1

[17] J. R. Rosell, X. Ortega and X. Dies, "Natural and Artificial Radionuclides on the Northeast Coast of Spain," Health Physics, Vol. 60, No. 5, 1991, pp. 709-712. doi:10.1097/00004032-199105000-00010

[18] H. R. Saad and D. Al-Azmi, "Radioactivity Concentrations in Sediments and Their Correlation to the Coastal Structure in Kuwait," Applied Radiation and Isotopes, Vol. 56, No. 6, 2002, pp. 991-997. doi:10.1016/S0969-8043(02)00061-1

[19] M. N. Alam, M. I. Chowdhury, M. Kamal, S. Ghose, M. N. Islam and M. N. Mustafa, "The ${ }^{226} \mathrm{Ra},{ }^{232} \mathrm{Th}$ and ${ }^{40} \mathrm{~K}$ Activities in Beach Sand Minerals and Beach Soils of Cox's Bazar, Bangladesh,” Journal Environmental Radioactivity, Vol. 46, No. 2, 1999, pp. 243-250. doi:10.1016/S0265-931X(98)00143-X 